\title{
21世紀の都市環境を目指して 一環境行政の課題亡展望一
}

\section{加藤 久和}

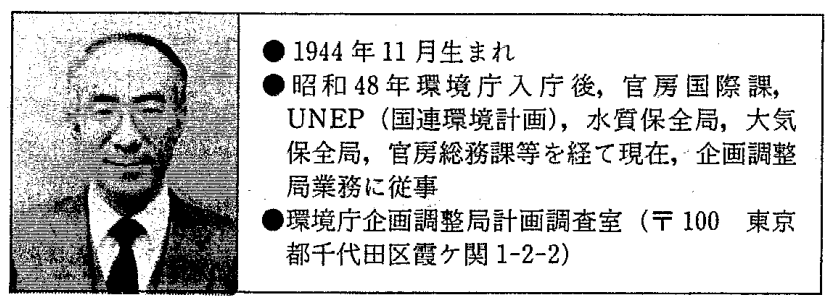

\section{1.はじめに}

21 世紀といっても，あと 10 年と少々を余すの みである。 21 世紀に入ってからのわが国の経済・ 社会の発展の潮流は，既に現在の経済・社会情勢 の中に芽生えていると言えよう。

しかし他方，10 年というのはあらゆる予測予 言や計画目標がはずれるほど長い期間という見方 もできる。事実，過去 10 年間のわが国の産業構 造の変化や技術革新，国際化の進展ぶり，国民の 生活様式の高度化，多様化，そしてそれらと深く かかわり合った環境問題の態様の変化を見ると, 21 世紀はおろか，今後の 10 年間における環境問 題の行く方を論ずることさえち叻うちょされる。

再びしかし，物質的な生活水準が一応満たされ た今日，精神的なうるおいや快適性を求める人久 の環境に対する認識や行動は短期間のうちに大き く変化する可能性を秘めている。近年，住民自ら の手による河川, 公園緑地などの身近な生活環境 の改善活動, リサイクル運動, まちづくり運動な どの隆盛, 更には地球的規模の環境問題や開発途 上国の貧困と環境破壞の悪循環（“持続可能な開 発” のあり方）に対する国民的関心の高まりに は，目を見はるものがある．自然環境の保全を含 め, “生活の質” の向上を求める国民の意識, 欲
求もまた高度化，多様化しており，むしろこれを 21 世紀の環境づくりに向けて積極的に導いてい くことは, 今後の環境行政における重要な課題の 一つであり，望ましい環境像の実現に有力な手が かりを与えてくれるものと思われる。

そこで以下には，本特集号のテーマである都市 環境の問題を中心として，まず，今後のわが国の 社会, 経済の動向を概観し, その上で環境行政に おける課題と対応の方向を展望してみることとし たい.

\section{2. 都市化と人口の高齡化の進展}

都市とは，何より人口の集積を意味する. わが国の総人口は，今後増加率は鈍化するもの の緩やかな増加が続き, 西暦 2000 年には約 1 億 3100 万人， 2010 年前後には 1 億 $3500 \sim 3700$ 万 人のピークに達し，その後緩やかな減少に転ずる と見込まれている。このすう勢の中で，人口の高 齢化が急速に進みつつあり，65歳以上の総人口 に占める割合は，現在の $11 \%$ 強から 2000 年には 16\% 強，更に 2025 年には19～22\%にもなって 現在の高齢化先進国たる一部西欧諸国をも追い抜

くと予想されている.

都市化の進行についても，これまでのような都 市への急激な人口の流入・集中は避けられるもの の，市街地の外延的拡大を伴いながら依然として 進展し，DID（人口集中地区）居住人口の総人口 に占める割合は，現状の約 6 割から 2000 年には 約 7 割，2025 年には約 8 割に達すると見込まれ る。

大都市圏, 地方圈別には, 近年特に東京圈が再 
び増樊を見せていることもあって予测が困難であ るが，相対的には現在都市化の度合いが低い地方 圏における都市人口の伸びが大きいと考えられ る。ただし，その地方圈の中でも県庁所在地など の中核都市への人口集中の傾向が強く，地域内の 過密, 過疎化が同時並行的に進行し, 地方の中小 都市に扔いては，交通網の整備ともあいまって， 比較的低密度, 拡散的な市街化が進むものと思わ れる。

人口の高齢化の影響は, 過疎化の進行する地方 圏の市町村で最も深刻に現れるが, 最近は高齢者 層が大都市圈または地方中核都市の近郊に定住す る傾向も出てきており，これらの都市にとっても いかにして高齢者にも安全，健康的で快適な住み やすい環境を創り出していくかが大きな課題とな ろう。

いずれにしても，かくて 21 世紀初頭には国民 の大多数が都市内または都市的環境と都市的生活 様式の中で居住するようになることは疑い得な 々.

\section{3. 都市化，技術革新の進展と都市環境}

都市化の進展は, 都市活動の増大と都市的生活 様式の普及を意味する。

技術革新や情報化の進展に支えられたわが国経 済のいっそうのサービス産業化, ソフト化, 生 産・流通・貿易構造の自由化, 国際化ともあいま って, 社会全体としてのエネルギー・資源の利用 効率は高まっていくものの, わが国の経済規模自 体の拡大基調が続く中で, 都市に扔けるエネルギ 一その他産業用, 生活用物資に対する需要は引き 続き増大していくと見込まれる。したがって，そ れらの物資や人を運ぶ交通システムに対する需 要, とりわけいっそうのモータリゼーションと生 活様式の高度化に伴う貨物輸送の長距離・小口・ 多頻度化による自動車交通量と航空機による都市 間の貨物輸送量も, 飛躍的に増大すると考えてよ いだろう。

既に人口, 産業の集積度が高く, 高密度の活動 が営まれる大都市圈においては, 交通公害問題, 都市内中小河川や湖沼, 内湾などの水質污濁問 題, 廃棄物の処理と最終処分地の確保の問題, 近
隣騒音問題など，広範多岐にわたる環境問題（そ れも従来のように産業公害というより，都市活動 や都市的生活様式，そしてそ扎らを支える都市構 造そのものに起因する，い扔仂る都市・生活型公 害のウエイトが高まってきている)を抱えてお り，都市化のいっそうの進展は，こうした問題の 解決を一段と困難にするおそれがある。地方圈に 扔いても，人口の都市集中や都市的な生活様式の 普及に伴い, 都市的な環境問題が広がるおそれは 十分にある。

また, 都市化の進展は, 都市周辺部への市街地 の拡大と都市内に抢ける農地, 樹林, 緑地などの 自然的環境の減少をも意味する。一方，国民の生 活水準は更に向上し, 自由時間の増大ともあいま って, 国民の意識は精神的, 文化的な欲求の充足 へと変化し生活の質の向上や自然とのふれあいを 求める声がいっそう強まるであろう。

他方で，都市住民のための別荘地（またはセ力 ンドハウス）開発圧が高まるとともに，自然環境 の中でのスポーツ・レクリエーション活動や長期 滞在型旅行が盛んになると予想され, 都市近郊や 農山村地域の自然環境の保全については, 慎重の 上にも慎重な配慮をすることが不可欠になる。

こうして，都市住民に身近な緑や水辺などとの ふれあいの機会を数多く提供したり，うるおいと 安らぎのある快適な都市環境を積極的に創り出し ていくことがますます重要となろう。21世紀に おける本格的な長寿社会の到来を控えて, まだ比 較的に生産年齢人口比率が高く経済社会の活力が 維持されているここ 10 数年の間に, 生活の質の 向上に向けて下水道, 公園緑地等の社会資本の整 備を図っていくことが強く求められており, 環境 行政としてもこれを積極的に支援, 推進していか なければならない。 また，地域の特性に応じて， たとえば下水道, 河川の直接净化, 小型合併浄化 槽などの施設を有機的に組み合わせた総合的な水 管理システムの整備を促進する必要がある。

都市住民の間では生活様式・価值観の多様化, 自由時間の増大, 人口の高齢化などを背景とし て, 自主的な生涯教育や社会活動への参加に生き がいを見いだそうとする傾向が強まると予想され るが, 都市の生活環境の改善や自然保護, 歴史的 景観の保全, そして快適環境の創造へ向けてのま 
ちづくりは，こうした人々の格好の活動対氯とな り得るものである。環境行政としても，これらの 活動を支援すべく，種々の政策手段を講じていく 必要がある。

更に，都市に限らないが，物の生産・流通・消 費をはじめ建設，交通，通信，廃裹物処理等広範 な分野にわたるいっそうの技術革新の進展は，環 境への負荷を減らすような方向でわが国の経済構 造を再編し，都市を再構築していく道を切り開い てくれる一方で，環境への影響が未知の新技術や 多数の化学物質を生み出し，その利用拡大と使用 形態の変化をもたらすとともに，廃妄物の性状変 化をもたらし，その適正処理を複雑・困難にする 可能性がある．事前の慎重な環境アセスメントお よびあらゆる環境媒体を通じた（クロスメディ ア・アプローチによる): 総合的なリスク・マネー ジメントが必要になるゆえんである。

ちなみに，最近いちやく脚光を浴びている大深 度地下空間の利用可能性についても，背景に地下 掘削技術の大きな進歩があるとはいえ，大深度地 下での掘削，建設作業や地下空間の利用，居住な ぞに伴う環境のみならず人の健康や精神的側面へ の影響については，ほとんど何も解明されていな いのが実態である。

\section{4. 都市生態系の再生に向けて}

さて，以上述べてきたところを通観すると，21 世紀を目指しての環境行政推進上の主要な課題 は, (1) 環境污染の未然防止と排出管理の徹底,

(2) 生態系の保全, (3) 環境資源の保全と活用の三 つに大きく分けることができる。（11)未然防止に 関しては，今後とも環境行政の根幹をなすこと論 を待たないのでここでは省略し，以下には都市環 境をめぐる(2)と(3)の課題について，今後の環境政 策の展開をみることとしたい。

わが国の自然保護政策は，これまで貴重な自然 や優れた風景の保護に重点を置いてきたが，今後 はそのような観点に加え，よりいっそう自然のメ カニズムにまで踏み込んで，その地域の植生，鳥 や昆虫などの生物相をも含めた生態系そのものの 保全を積極的に推進していく必要がある。

都市やその周辺に残された樹林地, 水辺などの
身近な自然についても，それ貴重な生態系とし てとらえ，多様な生物が生育できる環境として， 都市に抢ける自然生態系の分布と相互のネットワ 一クの形成にも配慮しつつ，多角的な手法により 保全，創出していくことが必要である。事実，こ れまでにも国や地方公共団体をはじめ多数の民間 団体や企業によって緑地保全, 都市緑化などの努 力が重水られてきており，環境行政推進の立場か らもナショナル・トラストの設立, 自然環境保全 法人としての認知, 公益信託制度の活用, その他 民間団体や農地, 樹林地などの提供者に対する技 術的，資金的援助や税制・金融上の優遇措置など， 支援の手を差し伸べるべきことは多い.

身近な自然の生態系について人々の理解を深め るためには，「自然観察の森」のように都市周辺 において人々が自然とふれあえる場を整備し，自 然観察，野外教育などの場として提供するととも に，「身近な生きもの調查」のように広く国民の 参加を得ながら自然についての調查を実施するな どの旋策が必要である．今後は，都市内にもでき るだけ自然の状態に近いエコロジカル・パークや 野鳥やリスなどの身近な生き物のサンクチュアリ 一を設けていくことが望ましい。

都市の自然生態系の保全と水辺などのオープン スペースの確保を図り, 都市緑化を進めること は，単に都市環境の快適性（アメニティー）を高 めるばかりでなく，都市の水循環を回復させ，大 気污染や騒音に対する緩衝能を高めるとともに， 人工熱の放散による都市のヒートアイランド化や 乾燥化をも防ぐ大きな役割を果たすことが知られ ている，更に，都市活動の基盤である水，エネル ギー，物質などを自立的，循環的に利用すること により，都市自体を環境に負荷を与えにくい構造 とすることも重要である，たとえば，水の自立 的・循環境的利用としての雨水の貯留・利用設備, 中水道, 透水性舗装等や，エネルギー効率的な利 用方法としての地域冷暖房, コジェネレーショ ン・システム, 廃棄物焼却場の余熱利用システム などの整備, その他廃棄物からの有用資源回収や リサイクル運動が各地で進められるようになって きた。

このため，環境庁においては今後，これらのシ ステムや運動を有機的に絡み合わせ, 計画的にま 
ちづくりや都市雨開発の中に採り入れていくこと を目指した「環境保全形都市システム整備計画」 （エコポリス計画）の策定を推進することとして いる。また，消費者の環境保全意識を高婂苛とと もに，環境への負荷の小さい，または環境保全型 の商品の選択を促すため，当該商品にマークを付 けて販売・普及させる「エコマーク」事業や業務 用小型ボイラなど低 $\mathrm{NO}_{x}$ 型の優良機器推奨事業 も近々実施することとして㧍り，これらの事業の 趣旨が国民の間に広く普及浸透することが望まれ る.

\section{5. 環境資源の保全と活用}

水と緑，土壤などの環境は，自然浄化，気候緩 和などの機能を有するのみならず，経済的にも， また生命・健康の保持，快適性などのさまざまな 面でも価值を持つ有限な資源であり，現在の世代 のみならず将来の世代にとっても貴重な資源であ る。国際的にも，「環境と開発に関する世界委員 会」の報告書にみられるように，「持続可能な開 発」のためには環境資源の適切な保全と活用が必 要であるという認識が定着しつつある。

環境資源の適切な管理のためには，環境資源の 価值を総合的に評価するためのデー夕整備を行う とともに，生態系のメカニズム，環境容量，地域 住民の快適性に対する選好などを勘案した指標の 開発などを進めることにより，地域の自然的，社 会的条件を踏まえた環境資源の適正な保全，利用 および創造を図るためのビジョンや目標を示す必 要がある。

環境庁においても望ましい都市環境の評価尺度 としての「都市環境指標」の開発に着手したとこ ろであるが，地方公共団体においては，環境保全 のための各種施策に結合し，総合的かつ計画的な 環境施策の推進を図ることを目的とした「地域環
境管理計画」を策定するところが增えてきてい る。これらは，各種の環境利用に当たっての配慮 指針としての役割と，環境資源の適切な保全と管 理を地琙レベルで目指すきのであり，環境庁とし てもこのような計画の策定作業に補助を行ってき た.

また，地方自治体によるアメニティータウン計 画やアメニティーマスタープランの策定を推進し ているところであるが, 今後はこれらの計画の具 体的事業化のため, 関係省庁とも近密に協力して 地方自治体を支援する体制を整えていく必要があ る。

とりわけ，各種の都市活動が高密度に営まれる とともに今後臨海部などにおいて大規模かつ広域 的な開発が予想される東京, 名古屋, 大阪を中心 とする三大都市圏では，開発に当たっては環境へ のさまざまな配慮を行うとともに，広域的視点に 立って環境資源の適切な保全・活用を図っていく 必要がある。そこで環境庁に扔いては，三大都市 圏の広域環境管理指針策定のための調査検討を行 っているところであり，更に，近年大規模な開発 構想が集中している東京湾地域については，水域 環境および大気保全のための調査研究を開始した ところである。

\section{6. おわりに}

こうして地域の環境資源の特性と制約条件を踏 まえた個性とアメニティーあふれる環境保全型の 都市（エコポリス）が地方圈にも続々誕生してく れば，大都市圏への人口集中に歯止めがかかるば かりでなく，地方都市への人口の定住化が進み， ニュービジネスの立地環境としても魅力あるもの となっていくことが期待される。

（原稿受付 1988 年 11 月 15 日） 